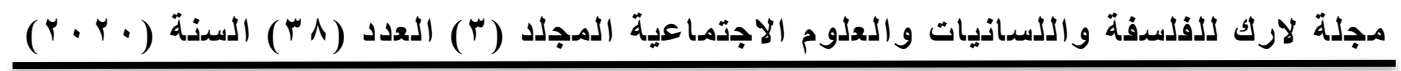 الأسباب الرئيسية لظهور الإسلام السياسي
}

\author{
مدرس مساعد: نئار ام على مجيذ \\ قسم أصول الاين، كلية العلوم الإسلامية، جامعة السليمانية ــ العراق
}

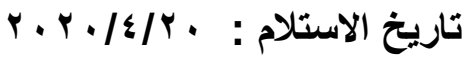 \\ تاريخ القبول : ؛/T/ •r +r
}

الخلاصة :

يعد موضوع الإسلام السياسي من المواضيع الحية والحساسة التي تطرح اليوم على بساط البحث والتحليل والنقاش، وتتاول من جوانب متعددة وزوايا مختلفة. وقد بدأ الاهتمام بالموضوع منذ انتصار الثورة الإيرانية في نهاية سبعينيات القرن المنصرم، ثم تطور الاهتمام به بعد انهيار الثيوعية في بداية التسعينيات، ومشاركة أحزاب إسلامية في الانتخابات في بعض الدول العربية والإسلامية. ومع ذلك فقد عدّ الباحثون وقوع بعض الحوادث والوقائع منذ منتصف القرن التاسع عشر كأسباب مؤثرة ورئيسية لظهور الإسلام السياسي، ومن هنا يأتي هذا البحث ليلقي الضوء على أهم تلك الأسباب.

الكلمات المفتاحية: الإسلام السياسي، الاستعمار، الصراع العربي_الإسرائيلي، الثورة الإيرانية، الحرب السوفيتية-الأفغانية 


\title{
The Main Causes of the Rise of Political Islam
}

\author{
Assistant Lecturer: Aram Ali Majeed \\ Department of Principle of Religion, College of Islamic Sciences, University of \\ Sulaimani, Iraq \\ Email: aram.majeed@ univsul.edu.iq \\ Phone No.: +9647501324032
}

\begin{abstract}
One of the most controversial topics that are argued about among many scholars nowadays is Political Islam. The significance of this appeared widely after the success of Iranian revolution in the previous century, and then the Soviet Union's breakdown in the beginning of 1990s that flamed the desire for recruiting and supporting Islamists, and the active participating in elections in some Arab and Islamic countries. Despite that, the occurrence of some other factors, in previous century, caused momentum to the appearance of political Islam. Hence, this paper comes to shed light on the most important of those reasons and factors.
\end{abstract}

Keywords: Political Islam, Colonialism, Arab-Israeli Conflict, Iranian revolution, Soviet-Afghan war. 


\section{Introduction}

After passing nearly two decades of the 21 st century, still political Islam continues to be a major existence within government authorities and oppositional parties from Morocco to Indonesia. Some Islamic states, moreover, have appeared and shaped in Sudan, Afghanistan, and Iran. Islamists have also a chance of being members of parliaments, presidents, and holding significant possessions within the governments from Arab countries to Southeast Asian states. Simultaneously, oppositions and radical groups have desired to destabilise states in Muslim lands and Western countries as well (Esposito, 2000, p. 49; Esposito, 2015, p. 1071). Martin asserts in the years following the I World War the existence of political Islam could be seen in organized movements, intellectuals and Muslim journalists. The most active movement that influenced many youths and represented this trend was Muslim Brotherhood (Martin, 2004, p. 537).

According to Fuller (2003, pp. 8-9), there were some dramatic and seminal events, in the late 19th and early 20th century, that caused to the catastrophic weakness of the Islamic world, such as the ruin of Ottoman Empire by Western imperialism and founding the secular state of Turkey and dividing Muslim lands into some independent states by the Western imperial order, and the hegemony of imperialism over every Arab and Muslim states as well. In spite of establishing the Israeli state in the heart of Muslim lands, exporting European political ideologies like socialism, Marxism, communism, nationalism and fascism produced controversial debates between adopters of these ideologies and Islamists.

The European hegemony and the rise of new national and independent states in the Islamic world and the establishment of secular states based on Western order, contributed to effectively decay and displace the important role of traditional Muslim scholars (Ulama), in the new states. This alteration required Ulama to 
protest social Westernisation and engage in reforming Islamic thought and advocate political Islam as a redeemer of Muslim lands (Campo, 2009, pp. 684-685). The clearest examples of these scholars were Rifa'a Rafi al-Tahtawi (1801-73), Khayr al-Din al-Tunisi (1810-89), Jamal al-Din al-Asadabadi al-Afghani (1838-97), Abd al-Rahman al-Kawakibi (1849-1903), Muhammad Abduh ibn Hasan Khayr Allah (1849-1905), Rashid Rida (1865-1935), Aziz Ustad Bediuzzaman Said al-Nursi (1877-1960), Ayatollah Ruhollah Khomeini (1902-89), Abu al-Ala al-Maududi (1903-79), Hasan al-Banna (1904-49), and Sayyid Qutb (1906-66) (Jawad, 2001, pp. 143-144; Othman, 2018, p. 108). The occupation of Muslim lands paved the way for Ulama actively participated in the political process (Bachar et al., 2006: p. $1-2)$.

Moreover, the failure of Arab nations in the 1967 Six-Day War and the October War of 1973 against Israeli forces, the oil embargo of 1973, the success of Iranian revolution of 1979, and ultimately supporting Western forces that enabled the Jihadi groups to withdraw the Soviet Union troops in Afghanistan, all paved the way for Islamists to take political opportunities to raise their flags and slogans within the Muslim-majority countries. (Campo, 2009, pp. 684-685). Moreover, Fuller (2003, p. XII) emphasises, after aforementioned events, political Islam has appeared as an international issue which associated to many aspects of economy, society, ethnicity and politics.

For the term 'political Islam' there are numerous definitions and explanations. The most common definitions, in this paper, can be presented and utilized. For example, Voll and Sonn (2010, p. 5) supposes that 'the term political Islam relates to the movements speak on behalf of current political motivation under the banner of Islam'. Richard Martin states that political Islam demonstrates Islam as a faith, performing values, and also establishing a stable state. These demonstrations were 
constructed by some reform scholars in the two last centuries. (Martin, 2004, p. 536). Fundamentally, the advocators of political Islam propose that despite having a body of faith, there are many things in Islam that cannot be ignored, such as organizing the society and politics in the modern world of Islam (Fuller, 2003, p. xi).

Some researchers, however, claim that the term of political Islam was not namely indicated in the Quran, Muslim Scripture, or in the Hadith, the Prophetic Tradition, at all. Yet, in the beginning, Islam was a governmental religion and practised politics. For instance, in the early Islamic government framework and by the time of Prophet Muhammad (peace be upon him), state rules and politics were obviously experienced. So, it can be said that "Islam was both a faith and political movement" (Masood, 2009, p. 25). Additionally, Alexander claims that during the period of Four Rightly Caliphs and aftermath political activities were executed and implemented (Alexander, 2007, p. ii).

Furthermore, Esposito declares that, after the revolution of 1978-79 in Iran, political Islam has been named by several terms, like "Islamic resurgence, Islamic revivalism, political Islam, and more commonly, Islamic fundamentalism" (Esposito, 1994, p. 8). Accordingly, it can be defined that Political Islam takes the way of political means to the aim of getting power and then changing the state and society, rapidly or gradually, to become more Islamic.

Regarding the scope of this study, Sami Zubaida's (2000, p. 62-3) explanation can be acknowledged, as he presents the basis ideology of Islamists in a classification that comprises 'conservative, radical and political Islam'. Based on Zubaida's typology, the Gulf states represent conservative Islam that mainly attempt to control their people morally and socially. The example of radical Islam can be seen in Islamic groups of Egypt who essentially rely on Sayyid Qut's ideology that struggle 
and revolt to eliminate the autocratic and un-Islamic rulers. Unlike the two previous types, in many respects, Zubaida classified political Islam as those who call for reform politics and society and represent a continuity with nationalist and leftist plans and, to some extent, they use the sources of two previous types as well.

There are many works in the literature have deal with political Islam and several of them pay attentions to important fragments of this field. Some scholars like John Esposito, Mohammed Ayoob, Olivier Roy, Gilles Kepel, etc, have greatly attempted to study and examine the Islamists and their works on this ground that would be highly respected. However, one of the significant aspects of studying in this area is investigating the main factors that caused appearance of political Islam and highlighting them within an independent study. Therefore, this paper will attempt to illustrate and investigate the main reasons that caused to the rise of political Islam in the twentieth century.

The question that requires to be answered in this paper is: "What are the key factors behind the rise of political Islam?". This study will contribute to the literature by studying the essential factors that caused to the rise of Islamists who have nowadays a significant role in shaping governments in northern African countries, Asian and the Middle East.

\section{The main causes of the rise of political Islam}

It is very crucial to notice that these factors below were not the solely factors behind this appearance. In the Muslim world, there were also many psychological, political, social, economic, even internal and external factors that paved the way for the rise and growth of political Islam. However, the major factors will be focused on within this paper. 


\subsection{The impact of some Muslim scholars}

At the end of the 19th century, the idea of return to the true Islamic principles were appeared and advocated by some notable Muslim scholars (Baram, 2014, p. 250). Examples of these scholars were Rifa'a al-Tahtawi (1801-73), the great Egyptian scholar, who promoted the theory that the citizens should obey their ruler, if the ruler attempts to please his citizens based on the God's obedience (Hourani, 1983, p. 76). Moreover, Jawad believes that Khayr al-Din al-Tunisi (Pasha) (1810-89) was also one of the eminent Ulama (Muslim scholar) who supported the idea of restraining the ruler by the law and consultation, and the ruler should obtain benefits from notables and Muslim Scholars (Jawad, 2001, p. 144).

In addition, Jamal al-Din al-Afghani (1838-97) as a prominent figure saw that the Islamic Community, Islamic Ummah, was suffering under the autocratic authorities who were incapable of protecting their citizens from external intervention, and despite that they raised the economic crisis in the Muslim lands (Haim, 1962: pp. 612; Alexander, 2007, p. 5). Concerning the rectification of the situation, al-Afghani suggested that Muslims should challenge and force their authorities to act in an effective manner and work for unification of their peoples under Islamic banner as the modern European Union (Jawad, 2001, p. 145). About the Muslim unity and emancipation, unlike Afghani, Muhammad Abduh (1849-1905) believed that, based on education and humanist principles, through social evolution Muslims could improve and reach the 'Islamic Golden Age'. From the view point of Abduh, to solve the miserable situation of Muslims and seek the way of constructing Muslim communities could be through political modification and the governmental constitution as well (Piscatori, 1986, p. 83).

The impact of Abduh's idea can be clearly seen on his famous disciple, Muhammad Rashid Rida (1865-1935). Rida was not satisfied with the Ottoman empire situation 
and, similar to his teacher, he hardly worked for reforming and seeking a way of awakening the Islamic community (Enayat, 1982, p. 69). Despite applying the Abduh's idea concerning the modern Islamic Golden Age through renewing and strengthening community, Rida explained solutions more morally and ethnically (Hourani, 1983, p. 222).

Similar to the previous scholars and thinkers, Al-Kawakibi (1849-1903) believed that through promoting and reforming religious education and law the decline of Islam and its community could be recovered, and he described the tyrannical rulers of the Muslim lands as shepherd "who treated his subjects as a cow to be milked" (Tauber, 1994, pp. 191-2). Al-Kawakibi stressed that under the corrupt rulers, who promoted evils and advocated 'false religion' and blind imitation, Islam had decayed and declined. Because of the significance of Arabic language and position of Arabian Peninsula, Al-Kawakibi believed Arabs were the nation who could protect Islamic moral principles from corruptions (Hourani, 1983: 272-3).

Hasan al-Banna (1906-49) was also one of the significant figures who had special impact on the following generations who became the supporters of political Islam later on. Al-Banna supported the concept of returning Muslim societies to Islam's original precepts and promoted the unity of Muslim Ummah through individual and then social reform (Al-Anani, 2013, p. 63). Milton-Edwards, moreover, indicates that to resist the effects of secularisation and westernisation, some Muslim scholars, like Al-Banna advocated the famous slogan 'Islam is the solution', and encouraged Muslims to return to the Prophet's era and his companions (Milton-Edwards, 2000, p. 129).

Sayyid Qutb (1906-66) can be seen as a modern Islamic revival and the Islamist ideologue that the young generations were greatly affected by his works to think about renewing and returning the Islamic principles. He believed that it is duty of 
individual Muslims rescuing society from pre-Islamic ignorance (Jahiliya), and then establishing the new Islamic Rule (Hakimiyah) (Sayyid Qutb, 1979, p. 97-8). Jawad argues that similar to al-Banna's writings, the works of Qutb promote the Islamic revival and returning Muslim society to the early Islamic community. Based on Qutb's theory, people do not need to obey their rulers, if rulers do not build 'a just society' (Jawad, 2001, p. 148-9).

As Khatab (2006, p. 1) claims that Sayyid Qutb is commonly seen as the Islamic political ideologue for contemporary militant and political parties. The concept of Jahiliah and the impact of his works, particularly the two famous books of (In the shades of the Qur'an) and (Milestones) which are originally written in Arabic, on the Islamists could/can be seen as weapons and threat to the autocratic regimes in Islamic world and to the Western countries as well. Because of special points of view concerning Jahiliyyah and Hakimiyah concepts, Qutb spent ten years in prison at the time of the president Gamal Abdel Nasser (1918-1970) in Egypt, and ultimately, Qutb was sentenced to death for his political viewpoints on governance issues and accusation of contemporary Muslim society as ignorance. Since then, Qutb has become a symbol of martyrdom of Islamists.

Same as Qutb, Maulana Abu al-Ala al-Maududi (1903-79) is considered as an Islamic revival who was the founder of Jamaat-i-Islami (Islamic Group) in 1941, in South Asia. Concerning implementing Shariah (Islamic law) and political objectives in an Islamic government, al-Maududi wrote many works which encouraged numerous Muslim authors, intellectuals, preachers and academists in Islamic world to resist Western hegemony and state despotism (Esposito, 1983, p. 99). Enayat, moreover, claims that al-Maududi believed the supremacy of Islamic Law that organize human life is the essential of an Islamic government (Enayat, 1982, p. 6). Similar to Qutb's theory, the state ignorance and modern Jahiliyyah were concepts 
that widely presented within the al-Maududi's works (Liu, 2013, p. 28). Brown claims that the works of al-Banna, Qutb, and al-Maududi can be seen as the most influential legacy of Islamists past and present (2000, p. 141).

These representative figures in the late nineteenth and twentieth century greatly influenced important Muslim scholars, intellectuals, writers and leaders (Martin, 2004, p. 536). The fall of the nationalist ideologies during fifties and sixties of the previous century produced the political Islam. In this regard, Esposito (2006, p. 146) claims that there were many founders and leaders of the modern Islamic movements, before establishing their parties, they were members of the nationalist movements. Examples of them are Hasan al-Banna, the founder and early leader of the Muslim Brotherhood in Egypt; Abbas al-Madani, the leader of the Algerian Islamic Salvation Front; Rashid Ghannoshi, the leader of Tunisian Renaissance Party; Necmettin Erbakan, the Welfare (Refah) Party founder in Turkey and so on.

\subsection{Occupation of Muslim lands and state repression}

It can be seen that the Muslim world under colonial domination, especially at the time of weakness of Ottoman Caliphate after the First World War, was a vital reason for changing the political viewpoint in the Muslim lands and the appearance of many Islamic groups (Ruthven, Nanji and Filali-Ansary, 2004, p. 116). For example, the occupation of Egyptian lands by British troops, in 1882, was caused to appear of the Muslim Brotherhood few decades later. This movement directed great number of youths to struggle for independence and the unity of Muslim communities (Hefner, 2011, p. 96). The branches of Muslim Brotherhood movement were 2,000 across Egypt in 1949, and proclaimed that they had approximately 500,000 members. At that time, the founder of Muslim Brotherhood declared that his movement was "a Salafi call, and Sunnite order, a Sufi reality; a 
political institution, a sports team, a cultural association, an economic company and a social concept" (Ayubi, 2003, p. 100).

Supporting the ideology of socialism and nationalism, in the Arab countries by some intellectuals like Taha Hussein (1889-1973) gave momentum to many Muslim intellectuals strongly rejected the idea of Western modernism and the ideology of independent states, yet they promoted unity of Muslim lands instead. Examples of this was al-Banna who believed that without social, intellectual and cultural liberation from secularism of the West, there was no real political independence. The main solution of this problem, as he believed, was 'return to Islamic rules and principles' (Jawad, 2001, p. 148). These kinds of intellectuals had influential impact on Muslim individuals who were always looking for a redeemer from colonialism and own dictatorships who produced a big gap between rich and poor. So, it was not difficult for Islamists to grow rapidly at that time because of supporting state authorities to Western colonial hegemony (Brown, 2000, p. 85-6).

Refusing Western ideologies and modern society by Sayyid Qutb was Similar to alBanna, but in a radical critique. In his famous book (Milestones), Qutb drew three key concepts concerning the society and the situation of Muslims in the world. Firstly, Qutb claimed that the recent societies can be seen as a similar societies of pre-Islamic era (Jahiliyyah) which acknowledge secular constitutions and Western ideologies instead of Sharia (Islamic law) (Qutb, 1979, p. 88-9). Secondly, the rulership of man (Hakimiyyah) was refused in any form by Qutb. He denied the Muslim state authorities who desired to rule the country and decay the divine sovereignty (Qutb, 1979, p. 84). Thirdly, he required a formation of new Islamic society that consisted of citizens who live based on Shariah law. This could be radically gained by the active participation of Islamist leaders, instead of working gradually on grassroots and individuals (Qutb, 1979, p. 99-100). based on Qutb's 
theory, Muslim leaders should spend their efforts on eradication of the secular states and Western hegemony and then establish a Muslim state that is ruled by Islamic legislation like the Prophet's era.

Masood highlights that while the Prophet of Islam aimed to provide a new lifestyle of individuals and establish a new state and solid community, it was hard for Muslims to live under the colonial authorities who were believed to have not similar perspectives concerning of a just society (Masood, 2009, p. 25). As Mutalib declares that, while most Muslim states now have embraced or have been embracing democracy as good system of government, many Muslims believed that democracy was incompatible with Islamic principles and was a Western imperialism extension that was imported to Islamic World against the new Muslim generation (Mutalib, 2006, p. 83).

One of the reasons of recruitment of Islamists in the previous century was state repression. For example, Mutalib also claims that governments sometimes hurt the innocents rather than the guilty, and these acts spawn the radicalism (Mutalib, 2006, p. 83). Such kind of state repression is also true to spawn Islamists who are going to get power by nonviolent means and winning elections. Fuller claims that in spite of all Western efforts for changing the Muslim world towards democratic governance, most parts of this world faced suffering under autocratic governments, totalitarian states and regimes ruled by the presidents-for-life (Fuller, 2003, pp. 9-10). The chance of Islamists to mobilise and recruit youths was autocratic regimes who were mostly supported by colonial and Western powers. However, Gerges (2003, p.75) highlights that, after 1950s, the U.S. policy eyes were more on 'revolutionary nationalism', rather than political Islam, to be a threat to Western interests in the region. 


\subsection{Arab-Israeli conflict and Palestine's issue}

The Israeli occupation of Palestine and the Arab-Israeli conflict in 1967 and 1973 made the decades long hostilities between Arabs and Zionist entity. The defeat of the combined Arab armies of Egypt, Jordan and Syria, in the 1967 Six-Day War against Israeli forces and the failures of the ideologies of Arab nationalism and socialism, as Esposito and Brown consider, transformed the Palestine liberation from local into a transnational issue in the Islamic world (Esposito, 2000, p. 50; Brown, 2000, p. 123). Milton-Edwards also believes that the defeats of Arab nations during the war against Israeli forces caused the resurgence of Islamists in the Arab countries where their leaders were unable to protect their lands (Milton-Edwards, 2000, p. 123).

This hostility between Muslims and Zionists has inflamed Islamic movements for years to grow rapidly, particularly in the Middle Eastern countries. Thus, the political hostile of many Islamic movements towards their secular states was increased alongside with protesting Israeli occupations. Examples of these kinds of movements were Egyptian Muslim Brotherhood, the Palestinian militant groups of Islamic Jihad and Islamic Resistance Movement (HAMAS) and the Lebanese Hezbollah militant group and political party, and many youth movements in Turkey, Iran, Iraq, Syria and so on (Campo, 2009, p. 56; Martin, 2004, pp. 740-1). The Palestine-Israeli conflicts, despite motivating a large number of Islamic parties recruiting youths, fueled the fire of the anti-Western perspective for their supports to the Israeli entity.

Furthermore, the Middle East situations, during the last decades of the twentieth century in particular, changed the Western perspectives towards the region. The defeat of Arab nations against Israeli troops, the European and American supports for the Israeli entity, the 1973 oil embargo as a response, and the most effectively 
the revolution of 1978-9 in Iran escalated the political Islam and made the Arabs and Muslims to consider establishment of Israel and Western supports to this entity is to subjugate the Middle Eastern countries and it was also considered as Western power to control the region. (Gerges, 2003, pp. 75-6) Esposito (2000, p. 50) and Brown (2000, p. 134), furthermore, highlight that the Arab-Israeli wars and the Zionist occupations of Muslim lands, and the civil wars and conflicts from Indonesia to Nigeria, during those decades, acted as catalysts for political Islam.

Milton-Edwards also presents that one anonymous member of the Liberation Party (Hizb ut-Tahrir), an international Islamic party that does not have a military wing, remarked: "We believe Israel will fall but first we have to return the people of Palestine to Islam, the same is true for all the Arab regimes of the Middle East. We are not waging a war of guns but a war of beliefs" (Milton-Edwards, 1996, p. 202).

\subsection{The Soviet War in Afghanistan (1979-89)}

Soviet Military intervention in Afghanistan in 1980s gave a strong reason for Islamist leaders and main figures to gather, train and operate on Afghan soil for ten years war. In this respect, Alexander refers to the facts that throughout this period, in support of the Mujahideen (the Afghan fighters) and struggle against Soviet Union, there were many Arab and Muslim volunteers went to Afghanistan to fight soviet troops (Alexander, 2007, p. 12). These volunteers received much financial and militant aids from Muslim countries like Saudi Arabia, Pakistan and even from European countries and the United States of America (USA). John Esposito (2000, p. 52) states that like the support of Iranian government to Hizballah against the Israeli occupation of Lebanon, the United States also supported the Afghan fighters to resist the invasion of Soviet Union in Afghanistan. Alexander (2007, p. 12) also claims that the military equipment and the Mujahideen Stinger missiles to shoot down helicopters were provided by the United States. 
After ten years war and killing thousands of civilians and fighters from both sides, the Soviet Union were forced to withdraw their troops from Afghan soils. As Reuveny and Prakash argue that the Soviet failure in Afghanistan assisted Mujahideen to believe that they could overcome obstacles and breakdown their enemies anywhere (1999, p. 963). After this success, the Arab-Afghan fighters reversed their struggle towards their government authorities who became the proWestern rulers in the Muslim lands and they returned to their countries with experience of battlefield and desire to resist, challenge and fight their authorities. For instance, one of the Afghan veterans who trained in Afghanistan for some years and then returned to Jordan, he threatened his government by stating that 'they will destroy the Kingdom of Jordan, if its authorities sign the Jordan-Israel peace accord' (Alexander, 2007, p. 12). In addition, Mutalib (2006, p. 83) claims that some of the radical groups, like Al-Qaeda, associated with Jihadi veteran and leaders, who returned to their countries from Afghan war, to use them for its interests.

David Commins and Thomas Hegghammer argue that, to some extent, the current Islamists can be seen as the produced foreign fighter that returned from Afghan war to their countries (Commins, 2006, p. 175; Hegghammer, 2010, p. 56-7). Some of them sustained their struggle and desire to fight in the battlefield until the present time within the Islamic extreme groups such as international Al-Qaeda, Boko Haram and the Islamic State in Syria, Iraq and Libya, while others shifted their path from conflict to political struggle.

\subsection{The Iranian Revolution (1978-9)}

There has always been considerable argument about the Iranian revolution, in 19789, as a major factor that paved the way for Islamists to growth dramatically in the 1980s and aftermath. Moreover, the fear of the West was surpassed when they were seeing that the Iranian authorities aimed to spread the revolution throughout the 
region and show this event as a lens to reveal the success of Islamists to establish the Islamic state (Esposito, 2000, p. 53). The establishment of the "mandate of the jurisprudent' (wilayat al-faqih) under Ayatollah Ruhollah Khomeini's (1902-1989) active role, in Iran, demonstrated the wide appeal of political Islam. The notable statement of Ayatollah Khomeini was that "in the absence of the last of the Shi'a Imams, the Mahdi, political leadership should be exercised by the ulama in general and the leading faqih in particular" (Alexander, 2007, p. 11).

The characteristic of Ayatollah Khomeini, as Hasan Baram claims, could be seen as a great religious and political leader who could establish the main frameworks of current Iranian government. Baram also shows that Khomeini always indicated his aggression towards the West, particularly USA, and claimed that he will wipe out the Israeli entity in the Middle East (Baram, 2014, p. 268-9). The Iranian revolution and its new government, Islamic Republic of Iran, gave momentum and new direction to the both Shiite and Sunni Islamists, and became a significant supporter for them, materially and emotionally. This revolution illustrated the Middle Eastern countries and the Islamic world could accept the political change like the European mould and this revolution was a vital evidence. Alexander claims that, despite his spiritual framework, Khomeini could obtain the Iranian attraction because of his great success in borrowing language of nationalists and Lefts. Moreover, he always argued concerning human rights and supporting oppressed people in Iran and the region, and in regards, he himself established the 'Foundation of the Oppressed' (Alexander, 2007, p. 11).

The Party of God (Hezbollah) was established as a Lebanese Shiite group in 1982 with supporting of Iranian authorities, just after the Israel occupations in Lebanon (Martin, 2004, p. 309). Hassan Nasrallah (b. 1960), as a revolutionary specialist, was supported by Iran to resist the occupations, and later on he became the secretary 
general of Hezbollah (Baram, 2014, pp. 168-9). After the defeat of Israel in Lebanon in 2000 and resisting the Hezbollah fighters during the eighteen-years-war, Hezbollah has become greatly enhanced in the region (Martin, 2004, p. 310). It is worth to mention that from the time of revolution until nowadays, as Abbas confirms, the aggressions against US interests and combating the West have been sponsored by Iranian government in the Middle East (Abbas, 2007, p. 59).

\subsection{The poverty and the economic crisis}

The economic crisis can be seen as one of the political change factors in Muslim majority countries in the last century and affected the lives of people. In this case, at the absence of governmental provision of basic needs, many Islamic groups could establish welfare services and social developmental activities and offer jobs, schools and health services. The popularity of Egyptian Islamists, as Kavli (2001, p. 3) believes, is not spiritually gratifying but because of providing solid solutions to the problems and crisis Islamists could become alternative power. Martin (2004, p. 310) also claims that the Lebanese Hezbollah party could establish and assist many 'hospitals, pharmacies, rehabilitation centres', educational institutions and scholarships, infrastructure, social and public services, and the party also supported many families who had been hurt as a result of war. Moreover, Özlem Tür Kavli considers the 'socio-economic factors' caused the rise of Islamists in the previous century, particularly in the 1970s and 1980s (Kavli, 2001, p. 2).

In many Muslim countries, being employment and finding jobs were, and still are, great problems for young graduates who have few work opportunities. For instance, one of the supporters of the Algerian Front Islamique du Salut (FIS, Islamic Salvation Front), concerning the economic situation of youth in Algeria, said:

"In this country, if you are a young man ... you have only four choices: you can remain unemployed and celibate because there 
are no jobs and no apartments to live in; you can work in the black market and risk being arrested; you can try to emigrate to France to sweep the streets of Paris or Marseilles; or you can join the FIS and vote for Islam." (Tessler, 2015, p. 122).

In such situations, the Islamists could mobilize youths against the unjust governments and made many of them the supporters of political Islam who were full of anger at their authorities and wanted them to be changed. For instance. Olivier Roy argues that, in the early 1970s, the Islamists could utilize the young educated, who were unemployment, and students on campuses in Pakistan, Afghanistan and Egypt, and then a decade later, in North African countries and Palestine, Islamists recruited many students as well (Roy, 1994, p. 51).

A prominent Iraqi Shia cleric, a Muslim writer and an Islamist figure, Muhammad Baqir al-Sadr (1935-80), presented that the Islamic governmental system can be adopted to reduce and eradicate the economic crisis that had been produced by the Western ideologies and local governments. (As-Sadr, 1984, p. xxi).

\section{3. conclusion}

In conclusion, it should be considered that the growth and escalation of political Islam and their impact on some nations and societies is a crucial topic within understanding global issues. Some main reasons can be seen as the factors that paved the way for political Islam to grow fast during last decades in the previous century, in the Islamic World. Based on this research, the most motivations on this growth can be seen as following:

- Many clerics and Muslim thinkers, in the two last centuries, considered that the Muslim authorities were corrupted and had lost their legitimacy of representation since they were not implementing Sharia rules. So that, based on 
their interpretations, those authorities must be resisted until they return to Sirat alMustaqim (the Right Path) of Islam. This type of explanation and interpretation of Islamic Sacred texts have an influence on generations until the present.

- The return to Islamic implementation of Sharia and establishment of the unification of great Muslim community was a strong motivation after the colonial hegemony and collapse of Ottoman empire in the 1920s. this was a key speech of Islamists to persuade Muslims following their groups and movements.

- The Palestine issue and the case of occupation of Muslim lands by Israeli forces drove many Islamic movements to participate political activities and, in some cases, get involved in military actions as well.

- The Arab nations' defeat in the war against Israel in 1967 and 1973 and the Western support for the Israeli entity raised the political thought in the minds of Muslims, and reached the conclusion that their state authorities could not restore the Muslim dignity. Therefore, the Islamist movements could be trusted in this case.

- The Soviet invasion of Afghanistan and defeat of their troops in front of Mujahideen, who received military supports from the West and Arab countries, encouraged many Islamic groups to be persuaded the defeat of great military forces of the world could be possible by such groups of Mujahideen.

- the 1979 Iranian revolution and the formation of Wilayat al-Faqih motivated and supported the framework of political Islam, particularly during the 1980s and 1990s. Thus, many political and militant groups have sought to repeat the Iranian experience in their lands with the support of Tehran. 
- The economic crisis under the authorities of Muslim states had, and still has, a profound effect on Muslims who always seek an alternative economic model that may shield the life of citizens.

- To some extent, Islamists in their area of influence could provide job opportunities to some people who were ignored by governments. This also gave the context for fast growing of Islamists who could establish schools, health services and centres.

Accordingly, further studies should be focused on, such as the modification of methods that political Islam has approached to reach the power and seek representing in parliaments in order to perform and practice their ideologies in ruling states which revealed the real face of political Islam.

\section{References}

Abbas, T. (Ed.). (2007). Islamic Political Radicalism: A European Perspective: A European Perspective. Edinburgh University Press.

Al-Anani, K. (2013). The power of the jama 'a: the role of Hasan Al-Banna in constructing the Muslim brotherhood's collective identity. Sociology of Islam, 1(1-2), 41-63.

Alexander, A. (2007). The Rise of Political Islam. Cheltenham, England: Understanding Global Issues Ltd. (148).

As-Sadr, B. (1984). Iqtisaduna: Our Economy. (Translated from Arabic) Volume 2. Tehran: World Organization for Islamic Services (WOIS).

Ayubi, N. (2003). Political Islam: religion and politics in the Arab world. Routledge.

Bachar, S., Bar, S., Machtiger, R., and Minzili, Y. (2006). Establishment Ulama and Radicalism in Egypt, Saudi Arabia, and Jordan. Center on Islam, Democracy, and the Future of the Muslim World/Research Monographs on the Muslim World, 1(4).

Baram, H. (2014). Insaiklopiay part u bzutnawa Islamiakan la jihanda [Encyclopaedia of Islamic parties and movements in the world]. Sulaymaniyah: Rahand Press. [Kurish Edition].

Brown, L. C. (2000). Religion and State: The Muslim Approach to Politics. New York: Columbia University Press. 
Campo, J. E. (2009). Encyclopedia of Islam. New York, NY: Facts On File.

Commins, D. (2006). The Wahhabi Mission and Saudi Arabia. London: I.B.Tauris.

Enayat, H. (1982). Modern Islamic political thought, The response of the Shi'i and Sunni to the twentieth century, London and Basingstoke: The Macmillan Press Ltd.

Esposito, J. L. (1994). Political Islam: Beyond the Green Menace. Current History: A Journal of Contemporary Wold Affairs, (579), 19-24.

Esposito, J. L. (2000). Political Islam and the West, en Joint Force Quarterly 24: 49-55

Esposito, J. L. (2006). Terrorism and the rise of political Islam. pp.145-158. In: Richardson, L. (Ed.). 2006. The roots of terrorism: Routledge.

Esposito, J. L. (2015). Islam and political violence. Religions, 6(3), 1067-1081.

Esposito, J. L. (Ed.). (1983). Voice of resurgent Islam, New York: Oxford University Press.

Fuller, G. E. (2003). The Future of Political Islam, New York: Palgrave.

Gerges, F. A. (2003). Islam and Muslims in the Mind of America. The Annals of the American Academy of Political and Social Science, 588 (1), 73-89.

Haim, S.G. (1962). Arab Nationalism: An Anthology. California: University of California Press.

Hefner, R. W. (Ed.). (2011). Shari 'a politics: Islamic law and society in the modern world. Indiana University Press.

Hegghammer, T. (2010). The rise of Muslim foreign fighters: Islam and the globalization of jihad. International Security, 35(3), 53-94.

Hooker, V. M., and Saikal, A. (Eds.). (2004). Islamic perspectives on the new millennium. Institute of Southeast Asian Studies.

Hourani, A. (1983). Arabic thought in the liberal age 1798-1939. Cambridge: Cambridge University Press.

Jawad, H.A. (Ed.). (2001). The Middle East in the new world order. 2nd ed. London: MacMillan Press LTD.

Kavli, Ö. T. (2001). Protest in the name of god: Islamist movements in the Arab world. Journal of International Affairs, 6(2).

Khatab, S. (2006). The political thought of Sayyid Qutb: The theory of Jahiliyyah. Routledge. 
Liu, Z. (2013). Commentary on "Islamic State" Thoughts of Islamism. Journal of Middle Eastern and Islamic Studies (in Asia), 7(3), 22-42.

Martin, R. C. (Ed.). (2004). Encyclopedia of Islam and the Muslim world. New York: Macmillan Reference USA.

Masood, E. (2009). Science and Islam; a History. London: Icon Books.

Milton-Edwards, B. (1996). Political Islam in Palestine in an environment of peace? Third World Quarterly, 17(2), pp.199-226.

Milton-Edwards, B. (2000). Contemporary Politics in the Middle East. Cambridge: Polity Press.

Mutalib, H. (2006). Misunderstood: Political Islam in Southeast Asia. Harvard International Review, 28(2), p.84.

Othman, A. H., (2018). Fiquh al'awlawiat eind Bediuzzaman Said al-Nursi 'awlawiat al'iislah aldiyni wal-ijtimaei nmwdhjan, dirasat tahlilia, mawdueia li rasayil al-Nur [The First Principles of Fiqh in the Thought of Bediuzzaman Said Nursi: The Principles of Religious and Social Reform in the Risale-i Nur: An analytical, thematic study]. AL-NUR Academic Studies on Thought and Civilization, (17), 107-136. [Arabic Edition].

Piscatori, J. P. (1986). Islam in a World of Nation-states (Vol. 1). Cambridge: Cambridge University Press.

Qutb, S. (1979). Ma'alim fi al-Tariq [Milestones]. Beirut: Dar al-Shuruq. [Arabic Edition].

Reuveny, R., \& Prakash, A. (1999). The Afghanistan war and the breakdown of the Soviet Union. Review of International Studies, 25(4), 693-708.

Roy, O. (1994) The Failure of Political Islam, Cambridge, Massachusetts: Harvard University Press.

Ruthven, M., Nanji, A., and Filali-Ansary, A. (2004). Historical atlas of Islam. Harvard University Press.

Tauber, E. (1994). Three approaches, one idea: religion and state in the thought of 'Abd AlRahman Al-Kawakibi, Najib 'Azuri and Rashid Rida. British Journal of Middle Eastern Studies, 21(2), 190-198.

Tessler, M. (2015). Islam and politics in the Middle East: Explaining the views of ordinary citizens. Indiana University Press.

Voll, J.O. and Sonn, T., 2010. Political Islam: Oxford Bibliographies Online Research Guide. Oxford University Press. 
Zubaida, S. (2000). Trajectories of Political Islam: Egypt, Iran and Turkey. The Political Quarterly, 71, 60-78. 